\title{
Monitoring of organophosphorus pesticides and remediation technologies of the frequently detected compound (chlorpyrifos) in drinking water
}

\author{
Aly Derbalah ${ }^{1 *}$, Ahmed Ismail ${ }^{1}$, Sabry Shaheen ${ }^{2}$ \\ ${ }^{1}$ Kafr El-Sheikh University, Department of Pesticides Chemistry, Faculty of Agric. 33516, Kafr El-Sheikh, Egypt \\ ${ }^{2}$ Kafr El-Sheikh University Department of Soil Sciences, Faculty of Agric. 33516, Kafr El-Sheikh, Egypt \\ "Corresponding author: e-mail: aliderbalah@yahoo.com
}

\begin{abstract}
Studies on the currently used organophosphorus insecticides with respect to their environmental levels and effective remediation technologies for their residues in water have been considered as a source of major concern. This study was carried out to monitor the presence of organophosphorus in drinking water plants (Kafr-El-Shiekh, Ebshan, Elhamoul, Mehalt Aboali, Fowa, Balteem and Metobess) in Kafr-El-Shiekh Governorate, Egypt. Furthermore, it was carried out to evaluate the efficiency of different remediation technologies (advanced oxidation processes and bioremediation) for removing chlorpyrifos in drinking water. The results showed the presence of several organophosphorus pesticides in water sampling sites. Chlorpyrifos was detected with high frequency relative to other compounds in drinking water. Nano photo-Fenton like reagent $\left(\mathrm{Fe}_{2} \mathrm{O}_{3}\right.$ (nano)/ $\left.\mathrm{H}_{2} \mathrm{O}_{2} / \mathrm{UV}\right)$ was the most effective treatment for chlorpyrifos removal in drinking water followed by $\mathrm{ZnO}$ (nano) $/ \mathrm{H}_{2} \mathrm{O}_{2} / \mathrm{UV}, \mathrm{Fe}^{3+} / \mathrm{H}_{2} \mathrm{O}_{2} / \mathrm{UV}$ and $\mathrm{ZnO} / \mathrm{H}_{2} \mathrm{O}_{2} /$ UV, respectively. Bioremediation of chlorpyrifos by effective microorganisms (EMs) removed $100 \%$ of the chlorpyrifos initial concentration after 23 days of treatment. There is no remaining toxicity in chlorpyrifos contaminated-water after remediation on treated rats with respect to cholinesterase activity and histological changes in kidney and liver relative to control. Advanced oxidation processes especially with nanomaterials and bioremediation with effective microorganisms can be regarded as safe and effective remediation technologies for chlorpyrifos in drinking water.
\end{abstract}

Keywords: chlorpyrifos, pollution, toxicity, water, remediation.

\section{INTRODUCTION}

Agricultural pesticides significantly improve crop yields and pesticides protect against pests. On the other hand, pesticides have become universal contaminants found in all segments of the environment and create many hazards to the environment and human health. Pesticides contamination in fresh water have emerged as an important environmental problem in the last few decades, and are causing concern with respect to long-term and low-dose effects on public health as well as non-target species ${ }^{1}$. The widespread use and disposal of organophosphorus compounds that have been used as an alternative to organochlorine compounds for pest control $^{2}$ resulted in the release of their residue into natural water, thus inducing an environmental problem ${ }^{3-4}$. Organophoshorus monitoring and measurements in fresh water need to be further developed by providing analytical tools to carry out advanced monitoring strategies in the environmental analysis.

Due to the great environmental and human risk of pesticide residues in water resources, pesticides monitoring and measurements need to be further developed by providing analytical tools to carry out advanced monitoring strategies in the environmental analysis. Furthermore, advanced methods are in demand for an effective treatment of pesticides-polluted water to achieve complete mineralization of target pesticides and to avoid the formation of toxic end products ${ }^{5-6}$. Advanced oxidation processes (AOPs), which are constituted by the combination of several oxidants such as Fenton reagent and zinc oxide combined with hydrogen peroxide, are characterized by the generation of very reactive and oxidizing free radicals in aqueous solution such as hydroxyl radicals, which poses a great destruction power ${ }^{5,7-8}$.
The ferric and zinc oxides nanocatalysts are very reactive because the active sites are located on the surface. As such, they have a low diffusion resistance and are easily accessible to the substrate molecules ${ }^{9-11}$. An important feature of nanomaterials is that their surface properties can be very different from those shown by their macroscopic or bulk counterparts ${ }^{12-13}$. The application of nanoparticles as catalysts of the Fenton-like and photo-Fenton reactions has been described by several investigators ${ }^{14-18}$. In comparison with their micro size counterparts, nanoparticles show a higher catalytic activity because of their large specific surface where catalytically active sites are exposed ${ }^{\mathbf{1 9}}$.The advantage of using nanoparticles as catalysts for Fenton-like reactions would more than offset the disadvantage (associated with the use of iron(III) catalysts) of requiring ultraviolet radiation to accelerate the reaction.

Bioremediation of hazardous wastes is a relatively new technology that has undergone more intense investigation as of recent decades. This process is focused on destroying or immobilizing toxic waste materials ${ }^{\mathbf{2 0}}$. Bioremediation is an option that offers the possibility to destroy or render harmless various contaminants using natural biological activity. As such, it uses relatively low-cost, low-technology techniques, which generally have a high public acceptance and can often be carried out on site ${ }^{21,46}$.

However, after remediation of pesticide residues in water, toxicity assessment is needed to directly assess the potential hazard of both original pollutants and its metabolites ${ }^{5,13}$. The use of AChE as biosensor seems to be the most appropriate technique for unambiguous determination of toxicity of water samples and wastewater at different stages of organophosphrus and carbamates degradation processes. The main advantages 
of AChE bioassays results from their selective sensitivity to organophosphates toxic photoproducts and prompts response, which enables online monitoring and control of photodegradation processes ${ }^{22-23}$.

In this study the presence of organophosphorus pesticides in drinking water in Kafr El-Sheikh governorate was monitored. The efficiency of advanced oxidation processes with different nano materials and bioremediation with effective microorganisms (EMs) were evaluated to achieve the total degradation of chlorpyrifos. The cholinesterase activity and histological changes in the liver and kidney of rats was measured to confirm the complete detoxification of chlorpyrifos-contaminated water.

\section{EXPERIMENTAL}

\section{Chemicals}

Chlorpyrifos with the purity of $99.5 \%$ was obtained from Central laboratory for Pesticides, Agriculture Research Centre, Cairo, Egypt. Organophosphorus mixture standard (Chlorpyrifos, dimethoate, dichlorvos, fention, mevinphos, phorate, tetrachlorovinphos, malathion, coumaphos, merphos, trichloronate and sulprofos) was obtained from Chem. Service, Inc 660, USA. Ferric chloride and Zinc oxide with $99 \%$ purity were obtained from EL-Gomhoria Company for Chemicals, Egypt. Zinc oxide (99.99\%) and ferric oxide (99.9\%) nanoparticles were obtained from Egypt Nanotech Company Limited, El-Wahaat Road 6th October, Giza, Egypt. The shape and size of ferric and zinc oxides nanoparticles are shown in Fig. $1 \mathrm{a}$ and b, respectively.

\section{Monitoring of the organophosphorus compounds in drinking water}

\section{Sampling sites}

Rosetta branch of Nile River feeds the main municipal water purification plants at Fowa, Metobess and Desouk (Mehalet Aboali). The Demitta branch of the Nile River divided into the Meat Yazed canal which feeds Kafr El-Sheikh area and the Terra Sea canal which feeds El-Hamoul, Beila (Ebshan) and Balteem (Elkhshaa) areas. Therefore, Fowa, Metobess, Mehalet Abuali, Kafr El-Sheikh, El-Hamoul, Elkhshaa and Ebshan water purification plants were selected as sampling sites to cover both the two Nile branches in Kafr El-Sheikh Governorate. These sampling sites were also selected according to their proximity to residential areas and agricultural activities. $3 \mathrm{~L}$ water samples in cleaned, sterilized and solvent washed glass bottles from each site (Kafr El-Sheikh, Fowa, El-Hamoul, Mehalet Abuali, Metobess, Elkhashaa and Ebshan) were collected for two times (spring and summer) in Kafr El-Sheikh Governorate. Samples were collected from the intake and outlet points of each water purification plant. Sampling from the intake point was carried out from the body of the running water that enter water purification plant while the sampling from outlet point was carried out from finished treated water in the purification plants. Bottles were rinsed twice with the sample water prior to filling and closing. The water samples were acidified with concentrated hydrochloric acid to inhibit the biological activity of the possible excite microorganisms. All
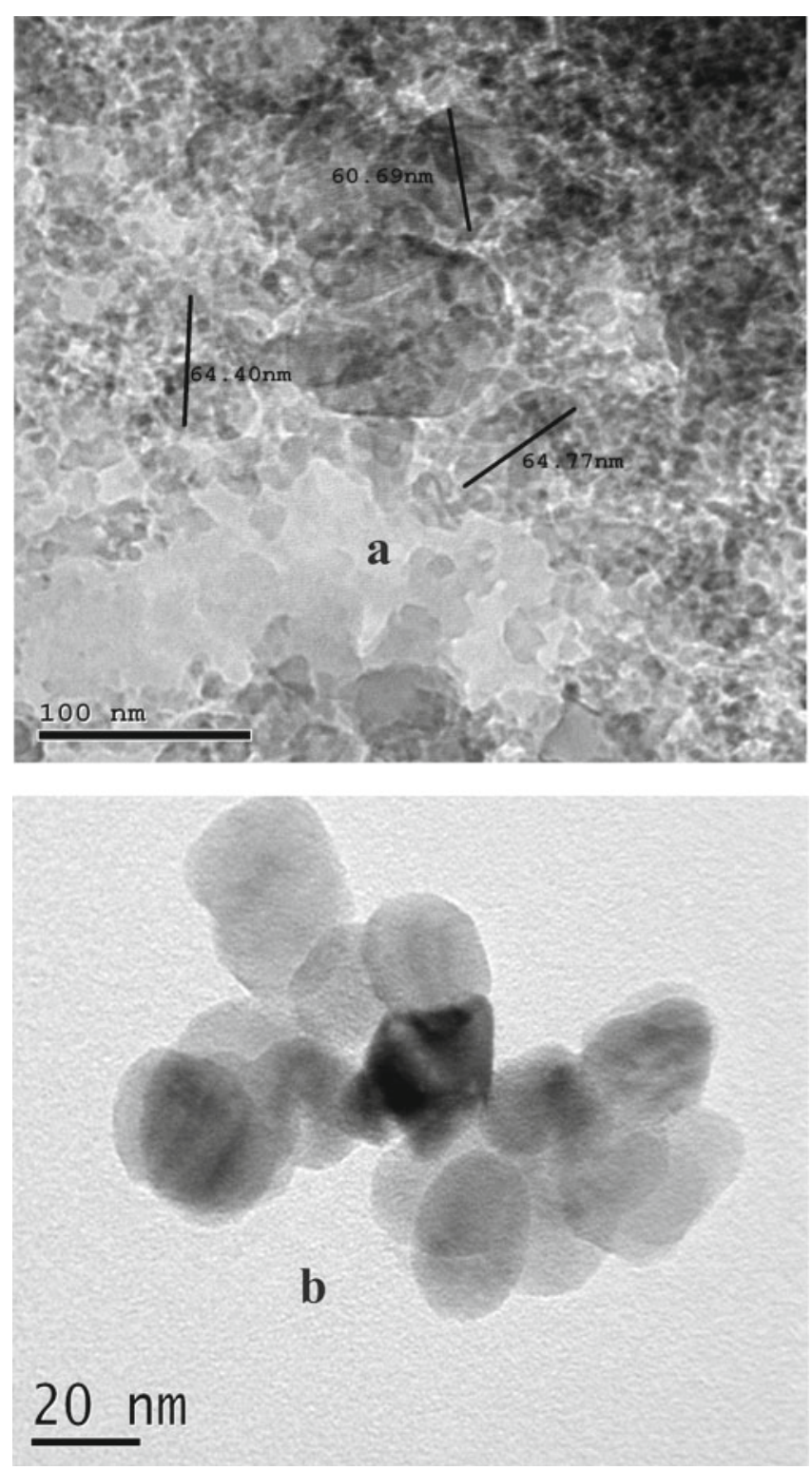

Figure 1. Transmission electron micrograph of ferric (a) and zinc (b) oxides nanoparticles

samples were clearly labeled by site number and sample date. Three replicates were collected from each sampling site. The samples were transferred to the laboratory in ice container for further treatments.

\section{Extraction procedure}

Water samples were filtered using filter paper (Whatman No. 1) to remove the sand and debris. The samples $(1 \mathrm{l}$, each) were partitioned twice with $50 \mathrm{ml}$ of methylene chloride and $10 \mathrm{ml}$ of saturated solution of sodium chloride. The samples were shaken vigorously; the organic layer was taken and dried on a column packed with $10 \mathrm{~g}$ of anhydrous sodium sulphate and then rotary evaporated to dryness at $30^{\circ} \mathrm{C}$. The residue was dissolved in $1 \mathrm{ml}$ of $\mathrm{n}$-hexane + methylene chloride $(1: 1 \mathrm{v} / \mathrm{v})^{\mathbf{2 4}}$. Sample fractionation and clean up procedure was carried out by loading onto $20 \%$ deactivated silica gel column (1 g) pre washed with $10 \mathrm{ml}$ of $\mathrm{n}$-hexane. The samples were eluted with $15 \mathrm{ml}$ of acetonitrile: petroleum ether (b.p. $\left.60-80^{\circ} \mathrm{C}\right)(5: 95 \mathrm{v} / \mathrm{v})$, and $15 \mathrm{ml}$ of acetone: ethyl acetate $(25: 75 \mathrm{v} / \mathrm{v})$. The two fractions were collected and 10 drops of a keeper solution of $1 \%$ paraffin oil in n-hexane were added to each fraction. The eluates were combined and dried under a stream of nitrogen 
and then re-dissolved in $0.3-\mathrm{ml}$ of $\mathrm{n}$-hexane. The efficacy of the analytical steps was evaluated by fortifying the distilled water samples with the mixture standard of organophosphorus pesticides at level of $1 \mathrm{mg} \mathrm{L}^{-1}$, and then the analytical steps (extraction, cleaning up and determination) that mentioned were performed and replicated three times. Good average percentages of recovery were obtained (data not published).

\section{Gas Chromatography - Mass Spectrometry analysis}

GC HP-6890/HP 5973 with Mass selective detector was used to detect the presence of organophosphorus pesticides in water. The instrument conditions were as the following: Column was HP-5 MS [30 m x $0.25 \mathrm{~mm}$ i.d. with $0.25 \mathrm{~mm}$ thick film of 5\% methyl silicone]; Carrier gas was helium at flow rate of $0.5 \mathrm{~mL} \mathrm{~min}^{-1}$. Inlet temperature was $225^{\circ} \mathrm{C}$ with injection volume of $1 \mu \mathrm{L}$ (splitless injector). The column temperature was set on $70^{\circ} \mathrm{C}$ for $1 \mathrm{~min}$ and then programmed at $10^{\circ} \mathrm{C} \mathrm{min}^{-1}$ to reach $200^{\circ} \mathrm{C}$. GC-MS interface was $280^{\circ} \mathrm{C}^{24}$. The three replicates of each sample were injected to calculate the mean concentration.

\section{Photochemical remediation}

The scope of the experiments included the following treatments: Nano photo-Fenton like reagent $\left(\mathrm{Fe}_{2} \mathrm{O}_{3}\right.$ (nano) $/ \mathrm{H}_{2} \mathrm{O}_{2} / \mathrm{UV}$ ), nano photo zinc oxide combined with hydrogen peroxide $\left(\mathrm{ZnO}(\right.$ nano $\left.) / \mathrm{H}_{2} \mathrm{O}_{2} / \mathrm{UV}\right)$, photo Fenton reagent $\left(\mathrm{Fe}^{2+} / \mathrm{H}_{2} \mathrm{O}_{2} / \mathrm{UV}\right)$ and photo zinc oxide combined with hydrogen peroxide $\left(\mathrm{ZnO} / \mathrm{H}_{2} \mathrm{O}_{2} / \mathrm{UV}\right)$. For the photo Fenton like reagent, a UV mercury lamp model VL-4. LC (80W) with wavelength range of 254-365 nm was employed for the irradiation of chlorpyrifos in aqueous solution. Ferric chloride and ferric oxide-nanoparticles were used as a source of iron. The solution was prepared by addition of a desired amount of chlorpyrifos $(5 \mathrm{mg}$ $\mathrm{L}^{-1}$ ) to the filtered drinking water from Metobess site (the highly contaminated site with orgnophosphorus compounds) and after that the mixture was carefully agitated. Then, freshly prepared ferric chloride or ferric oxide nanoparticles at concentration level of $50 \mathrm{mg} \mathrm{L}^{-1}$ as $\mathrm{Fe}^{3+}$ was added followed by the addition of $\mathrm{H}_{2} \mathrm{O}_{2}$ at concentration level of $0.05 \%$. Then the solution was completed with water up to $1000 \mathrm{~mL}$. The initial $\mathrm{pH}$ of the solution was adjusted at 2.8 with $1 \mathrm{M} \mathrm{HCL}$ for all experiments ${ }^{8}$. The solution was transferred from the standard flask to a quartz glass cell $(1000 \mathrm{~mL})$ and exposed to the irradiation of the UV lamp under constant temperature of $25^{\circ} \mathrm{C}$ with steering (the distance between the lamp and chlorpyrifos solution $15 \mathrm{~cm}$ ). The solutions from the irradiated samples were removed at regular intervals $(10,20,40,80,160$ and $320 \mathrm{~min})$ for HPLC analysis.

For $\mathrm{ZnO}$ catalyst, chlorpyrifos at concentration level of $5 \mathrm{mg} \mathrm{L}^{-1}$ with an appropriate amount of $\mathrm{ZnO}$ or $\mathrm{ZnO}$ nanoparticles $\left(300 \mathrm{mg} \mathrm{L}^{-1}\right)$ was shaken carefully before illumination followed by the addition of $\mathrm{H}_{2} \mathrm{O}_{2}$ at concentration level of $0.05 \%$. Then the $\mathrm{pH}$ was adjusted to 7 , the optimum $\mathrm{pH}$ for $\mathrm{ZnO}$ catalyst ${ }^{5}$. The suspension was left for $30 \mathrm{~min}$ in the dark prior to illumination to achieve the maximum adsorption of the pesticide onto the semiconductor surface ${ }^{5}$. The solutions from the irradiated samples were removed at regular intervals for
HPLC analysis as mentioned before elsewhere. Each experiment was replicated three times for accurate data.

\section{HPLC analysis}

The irradiated samples were analyzed directly by HPLC in the Central Laboratory of Pesticides, Agriculture Research Centre, Cairo, Egypt. A mixture of methanol and distilled water $(40: 60)$ was used as mobile phase under the isocratic elution mode. The flow rate was maintained at $1 \mathrm{ml} \mathrm{min}{ }^{-1}$ and the $\mathrm{UV}$ detector was employed at wavelength of $228 \mathrm{~nm}$.

\section{Bioremediation technique}

Effective Microorganisms (EMs1) formulation used for bioremediation of chlorpyrifos was obtained from the Egyptian Ministry of Agriculture, Cairo, Egypt. This formulation contains 60 species of beneficial microorganisms grow in special media and produced in Egypt under supervision of the Japanese EMRO Scientific Organization. The enrichment and propagation were carried out in sterilized $250 \mathrm{~mL}$ Erlenmeyer flask using mineral salt medium (MSM) $)^{25}$ and $5 \mathrm{ml} \mathrm{L}^{-1}$ of EMs liquid concentrate. Then the culture was prepared in sterilized $250 \mathrm{~mL}$ flasks containing $190 \mathrm{~mL}$ MSM, $10 \mathrm{~mL}$ EMs supplemented with chlorpyrifos at concentration level of $5 \mathrm{mg} \mathrm{L}^{-1}$. The cultures were incubated at $30^{\circ} \mathrm{C}$, $\mathrm{pH}$ (7) and $150 \mathrm{rpm}$ as optimum conditions for the growth of the tested effective microorganisms ${ }^{26}$. Samples were collected at $0,3,8,11,15,19$ and 23 days for the monitoring of the degradation of the tested insecticide. Control flasks of equal volume of MSL medium and the tested insecticide without the effective microorganisms were run in parallel at all intervals to asses a biotic loss. The collected water samples of the tested insecticide were filtered using syringe filtered $(0.2 \mathrm{~mm})^{26}$ followed by HPLC analysis as mentioned before. This experiment was repeated three times for accurate data.

\section{Toxicity test}

To confirm the complete detoxification of chlorpyrifos in treated water, toxicity tests were conducted on rats. Chlorpyrifos contaminated-waters after treatment with $\mathrm{Fe}^{3+} / \mathrm{H}_{2} \mathrm{O}_{2} / \mathrm{UV}, \mathrm{Fe}_{2} \mathrm{O}_{3}$ (nano) $/ \mathrm{H}_{2} \mathrm{O}_{2} / \mathrm{UV}, \mathrm{ZnO} / \mathrm{H}_{2} \mathrm{O}_{2} / \mathrm{UV}$, $\mathrm{ZnO}$ (nano) $/ \mathrm{H}_{2} \mathrm{O}_{2} / \mathrm{UV}$ and EMs were orally administrated to the tested rats. These tests were carried out to measure the effect of the possible remaining chlorpyrifos (parent or metabolites) in the water samples after remediation on rats with respect to acetylcholinesterase activity as well as histological changes in the liver and kidney of treated rats relative to control.

Adult rats (Sprague dauley) with the $100-120 \mathrm{~g}$ of weight, obtained from the faculty of Veterinary Medicine, Kafr-El-Shiekh University were used. The rats were housed in polypropylene cages under standard conditions with free access to drinking water and food. The animals were randomly divided into five groups each comprising three animals and the treated samples that possibly contain chlorpyrifos were given to rats as oral administration. Control group rats was fed with normal diet and given oral dose containing no chlorpyrifos. After 21 days, the rats were scarified under anesthesia and blood sample was taken by cardiac puncture in vials containing heparin. Plasma was separated and centrifuged at $4500 \mathrm{rpm}$ 
for $15 \mathrm{~min}$. The supernatant of blood sample was used to determine acetyl cholinesterase activity according to the method described by ${ }^{27}$. Enzyme activity data were statistically analyzed using one-way repeated measurement analysis of variance. Least significant difference (LSD) was used to separate means using SAS program (Version 6.12, SAS Institute Inc., Cary, USA). The kidney and liver organs were removed and prepared for histopathological examination according to the method described by ${ }^{28}$. The histopathology test was carried out at Dep. of Histopathology, Fac. of Veterinary Medicine, Cairo Univ. Egypt.

\section{RESULTS AND DISCUSSION}

\section{Monitoring of organophosphorus pesticides in drinking water}

The results of drinking water analysis from different sampling sites in Kafr El-sheikh Governorate have shown the presence of several organophosphate pesticide residues (dichlorvos, mevinphos, dimethoate, phorate, malathion, chlorpyrifos, fenthion, tetrachlorvinphos and coumaphos) either at the intake or outlet point of each water purification plant in the two sampling times (Tables 1-2). The concentrations of detected organophosphorus pesticides ranged from 0.070 to $2.95 \mathrm{mg} \mathrm{L}^{-1}$ either at the intake or outlet points of different water purification plants. With reference to the samplingre sites, temporal analysis in two sampling times showed that the organophosphorus pesticides were abundant in the following order; Metobess $>$ Kafr El-Sheikh $>$ Fowa $>$ Elhamoul $>$ Belia (Ebshan) $>$ Desuok (Mehallet Aboali) and Balteem (Elkhashaa), respectively. With respect to the detected compounds in all sampling sites during the two sampling times, the detection frequency was abundant in the following order; chlorpyrifos, dimethoate, dichlorvos, fention, mevinphos, phorate, tetrachlorovinphos, malathion, coumaphos, merphos, trichloronate and sulprofos, respectively.

The results of pesticides monitoring showed the presence of several organophosphorus compounds in water and this is in agreement with those reported by ${ }^{29-30}$. The concentration levels of the most detected organophosphorus pesticides were much lower at the outlet sampling points than the intake sampling points of water purification plants. Furthermore, some identified pesticides were detected in the inlet and not detected in the outlet points of water purification plants. This may be due to water purification processes such as coagulation, sand filtration and chlorination that carried out inside water purification plants that remove or reduce the residues of the detected pesticides in water ${ }^{31-35}$. For example, in drinking water treatment processes, coagulation with polyaluminium chloride was found to be efficient in the removal of organic materials ${ }^{31-35}$.

In spite of some pesticides still present in drinking water after treatment, their concentration level was much lower than the maximum residue limits (MRLs) according to Egyptian Standards. Finally, the misuse of these pesticides by concerned individuals in addition to the lack of or weak national control is behind the presence of these pesticides in water ${ }^{30}$. Therefore, frequent monitoring program is urgently needed in order to assess health risks associated with such contaminates, especially with chronic exposure or a life-long intake of contaminated drinking water.

\section{Degradation of chlorpyrifos by advanced oxidation processes}

The first parameter considered in this study was the losses in chlorpyrifos concentration with the irradiation time with respect to rate and the complete degradation of the tested compound. As shown in Fig. 2, the irradiation under nano-photo Fenton like reagent $\left(\mathrm{Fe}_{2} \mathrm{O}_{3}\right.$ (nano) $/ \mathrm{H}_{2} \mathrm{O}_{2} /$ $\mathrm{UV})$ gave the highest degradation rate of chlorpyrifos followed by $\mathrm{ZnO}$ (nano) $/ \mathrm{H}_{2} \mathrm{O}_{2} / \mathrm{UV}, \mathrm{Fe}^{3+} / \mathrm{H}_{2} \mathrm{O}_{2} / \mathrm{UV}$ and $\mathrm{ZnO} /$ $\mathrm{H}_{2} \mathrm{O}_{2} / \mathrm{UV}$ systems, respectively. A complete degradation of chlorpyrifos (100\%) was achieved under $\mathrm{Fe}_{2} \mathrm{O}_{3}$ (nano)/ $\mathrm{H}_{2} \mathrm{O}_{2} / \mathrm{UV}$ system followed by $\mathrm{ZnO}$ (nano) $/ \mathrm{H}_{2} \mathrm{O}_{2} / \mathrm{UV}, \mathrm{Fe}^{3+} /$ $\mathrm{H}_{2} \mathrm{O}_{2} / \mathrm{UV}$ and $\mathrm{ZnO} / \mathrm{H}_{2} \mathrm{O}_{2} / \mathrm{UV}$ systems within $80,100,160$ and $320 \mathrm{~min}$ of irradiation time, respectively (Fig. 2).

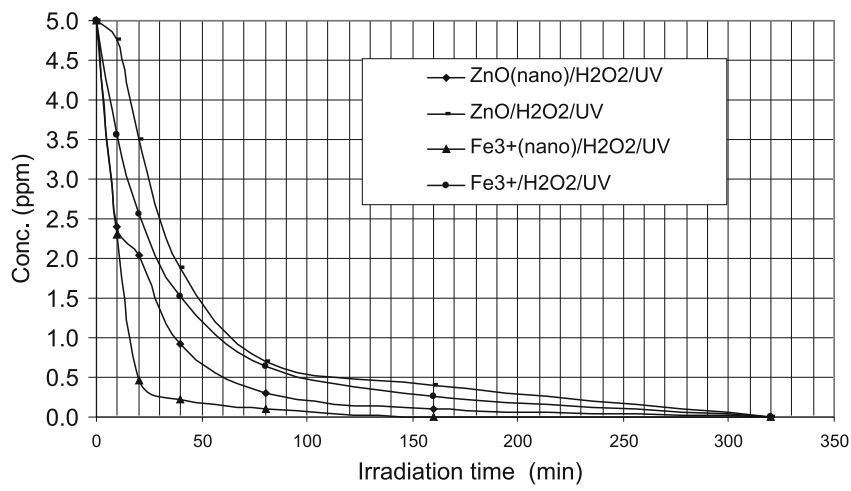

Figure 2. Degradation of chlorpyrifos at the initial concentration of $5 \mathrm{mg} \mathrm{L}^{-1}$ in drinking water under $\mathrm{Fe}_{2} \mathrm{O}_{3}$ (nano) $/ \mathrm{H}_{2} \mathrm{O}_{2} / \mathrm{UV}, \mathrm{Fe}^{+3} / \mathrm{H}_{2} \mathrm{O}_{2} / \mathrm{UV}, \mathrm{ZnO}$ (nano) $/ \mathrm{H}_{2} \mathrm{O}_{2} /$ $\mathrm{UV}$ and $\mathrm{ZnO} / \mathrm{H}_{2} \mathrm{O}_{2} / \mathrm{UV}$ systems

The degradation rate of chlorpyrifos was enhanced by irradiation under $\mathrm{Fe}_{2} \mathrm{O}_{3}$ (nano) $/ \mathrm{H}_{2} \mathrm{O}_{2} / \mathrm{UV}$ and $\mathrm{ZnO}$ (nano) $/ \mathrm{H}_{2} \mathrm{O}_{2} / \mathrm{UV}$ systems relative to the degradation under other photochemical remediation systems. This is due to the fact that the stabilized nanoparticles offer much greater surface area and reactivity which lead to higher generation rate of hydroxyl radicals relative to the normal particles ${ }^{36-37}$.

After 20 min of irradiation time, the degradation rate of the remaining chlorpyrifos was quite slower than the first $20 \mathrm{~min}$ under all photochemical remediation systems. This might be due to the low concentration of the remaining chlorpyrifos (lower than $5 \%$ of initial concentration) after $20 \mathrm{~min}$ of irradiation time which leads to high delivery rate of $\mathrm{Fe}^{+} / \mathrm{H}_{2} \mathrm{O}_{2} / \mathrm{UV}$ and $\mathrm{ZnO} /$ $\mathrm{H}_{2} \mathrm{O}_{2} / \mathrm{UV}$ systems corresponds to higher concentrations of these reagents and this subsequently increases their ability to compete with chlorpyrifos to react with hydroxyl radicals as hydroxyl radicals scavenger (eqs. 1, 2) ) $^{\mathbf{8}, \mathbf{3 0}}$. Also, chloride and carbonate ions naturally present in water react as hydroxyl radical scavenger ${ }^{41}$ as shown in equations 3 and 4 .

$$
\begin{aligned}
& \mathrm{Fe}^{2+}+\cdot \mathrm{OH} \rightarrow \mathrm{Fe}^{3+}++\mathrm{OH} \\
& \cdot \mathrm{OH}+\mathrm{H}_{2} \mathrm{O}_{2} \rightarrow \mathrm{HO}_{2}+\mathrm{H}_{2} \mathrm{O} \\
& \mathrm{Cl}^{-}+\cdot \mathrm{OH} \rightarrow \mathrm{Cl}++\mathrm{OH}^{-} \\
& \mathrm{CO}_{3}^{-2}+\cdot \mathrm{OH} \rightarrow \mathrm{CO}_{3}^{-\cdot}+\mathrm{OH}^{-}
\end{aligned}
$$

The degradation rate of chlorpyrifos under photo $\mathrm{Fe}_{2} \mathrm{O}_{3}$ (nano) $/ \mathrm{H}_{2} \mathrm{O}_{2} / \mathrm{UV}$ and $\mathrm{Fe}^{3+} / \mathrm{H}_{2} \mathrm{O}_{2} / \mathrm{UV}$ systems than 


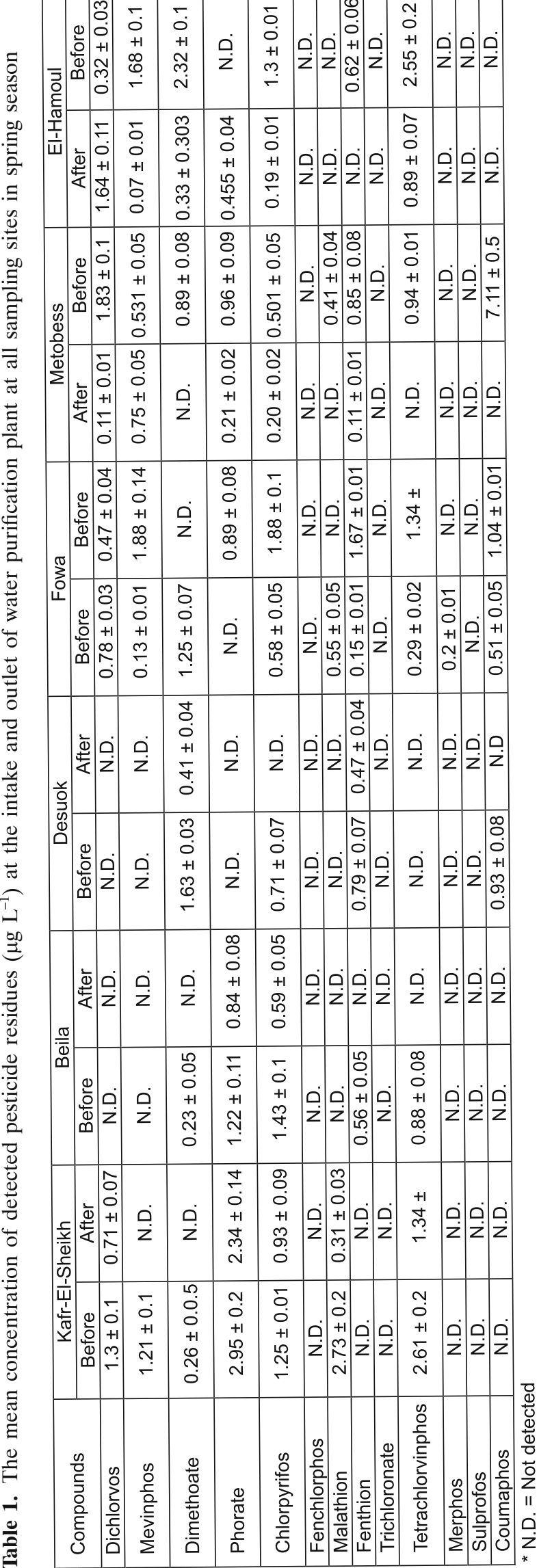

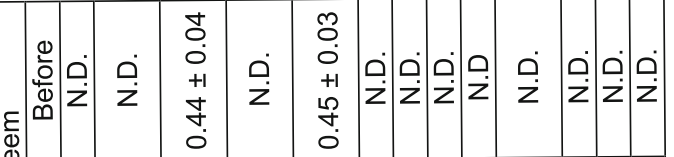

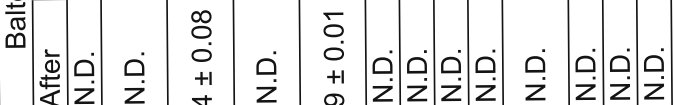

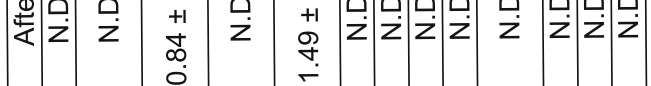

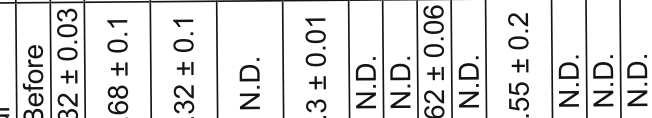

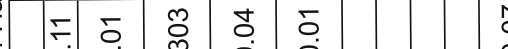

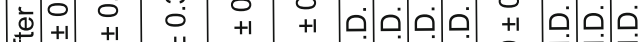

o. 0 .

ர.

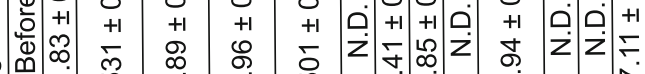

$\begin{array}{lllllllllll}1 & 0 & 0 & 0 & 0 & 0 & 0 & 0 & 0 & 0 & 0\end{array}$

< F

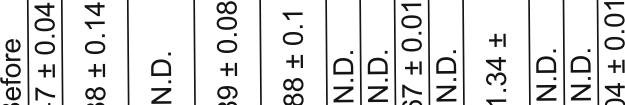

œ

ஜิ

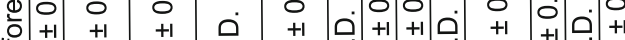

œ

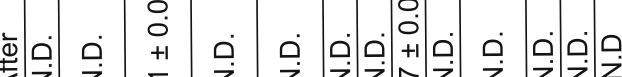

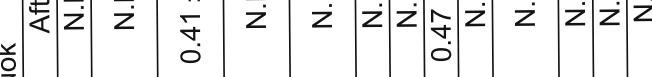

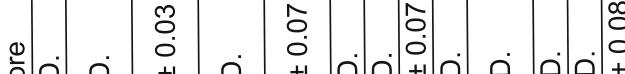

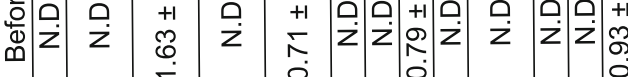

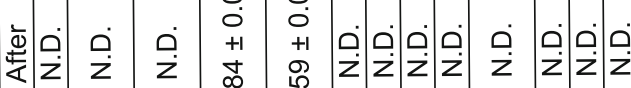

-

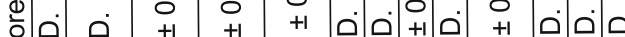

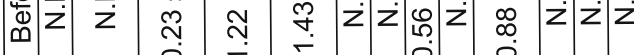

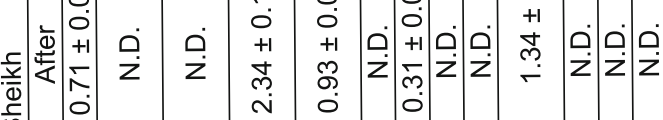

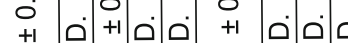

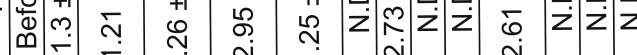

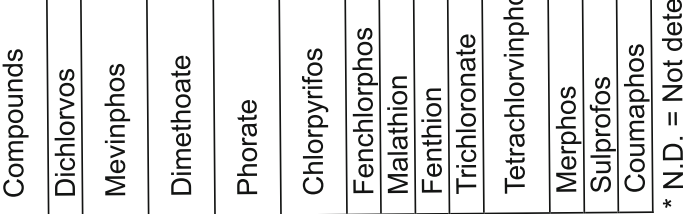

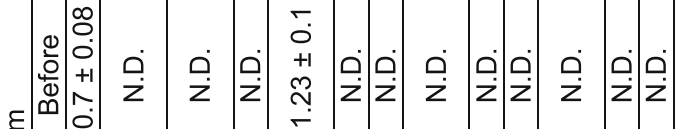
.

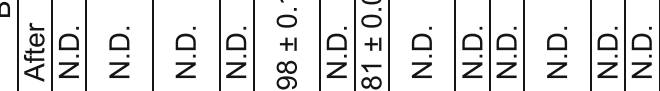

要

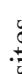

.

䆣

.0 
that under $\mathrm{ZnO}$ (nano) $/ \mathrm{H}_{2} \mathrm{O}_{2} / \mathrm{UV}$ and $\mathrm{ZnO} / \mathrm{H}_{2} \mathrm{O}_{2} / \mathrm{UV}$ systems. This may be due to the high generation rate of hydroxyl radicals under $\mathrm{Fe}^{3+} / \mathrm{H}_{2} \mathrm{O}_{2} / \mathrm{UV}$ relative to $\mathrm{ZnO} / \mathrm{H}_{2} \mathrm{O}_{2} / \mathrm{UV}^{\mathbf{5}}{ }^{42}$.

The degradation rate of chlorpyrifos under $\mathrm{ZnO}$ (nano)/ $\mathrm{H}_{2} \mathrm{O}_{2} / \mathrm{UV}$ system was higher than that under $\mathrm{ZnO} / \mathrm{H}_{2} \mathrm{O}_{2} /$ UV system and this was due to the effect of particle size of nano zinc oxide. The effect of particle size on the photodegradation efficiency can be ascribed to two reasons. (1) When the size of $\mathrm{ZnO}$ crystals decreases, the amount of the dispersion particles per volume in the solution will increase, resulting in the enhancement of the photon absorbance. (2) The surface area of $\mathrm{ZnO}$ photocatalyst will increase as the size of $\mathrm{ZnO}$ crystals decreases, which will promote the adsorption of more insecticide molecules on the surface ${ }^{\mathbf{4 3}}$.

The degradation rate of chlorpyrifos under $\mathrm{Fe}_{2} \mathrm{O}_{3}$ (nano) $/ \mathrm{H}_{2} \mathrm{O}_{2} / \mathrm{UV}$ system was higher than that under $\mathrm{Fe}^{3+} /$ $\mathrm{H}_{2} \mathrm{O}_{2} / \mathrm{UV}$ system and this is due to the effect of the nano size of ferric oxide particle. This is in agreement with $^{\mathbf{1 6 - 1 7}}$ who developed a new catalyst using nanosize particles with a high surface area that can accelerate the photo Fenton-like reagent. Therefore, ferric and zinc oxide nanoparticles are potentially useful for the remediation of chlorpyrifos contaminated water because they have a great surface area relative to normal size ones which led to a great destruction powder through hydroxyl radicals generation for chlorpyrifos ${ }^{43-44}$.

\section{Biodegradation of chlorpyrifos using effective microor- ganisms (EMs)}

The degradation ability of the effective microorganisms to chlorpyrifos was illustrated in Fig. 3. The effective microorganisms showed high potential in the degradation of the tested insecticide. Nearly $100 \%$ of chlorpyrifos initial concentration $\left(5 \mathrm{mg} \mathrm{L}^{-1}\right)$ was degraded within three weeks. On the contrary, the degradation percentage of chlorpyrifos reached $2 \%$ at the end of incubation time in control samples. This indicates that photodecomposition or volatilization of chlorpyrifos is negligible.

Concerning the bioremediation of chlorpyrifos, effective microorganisms showed high degradation ability against chlorpyrifos in drinking water. This may be due to that the effective microorganisms is not one microorganism but a mixture of microorganisms ${ }^{45}$ and has also been described as a multi-culture of coexisting anaerobic and aerobic beneficial microorganisms ${ }^{\mathbf{4 6 - 4 7}}$. Therefore, its

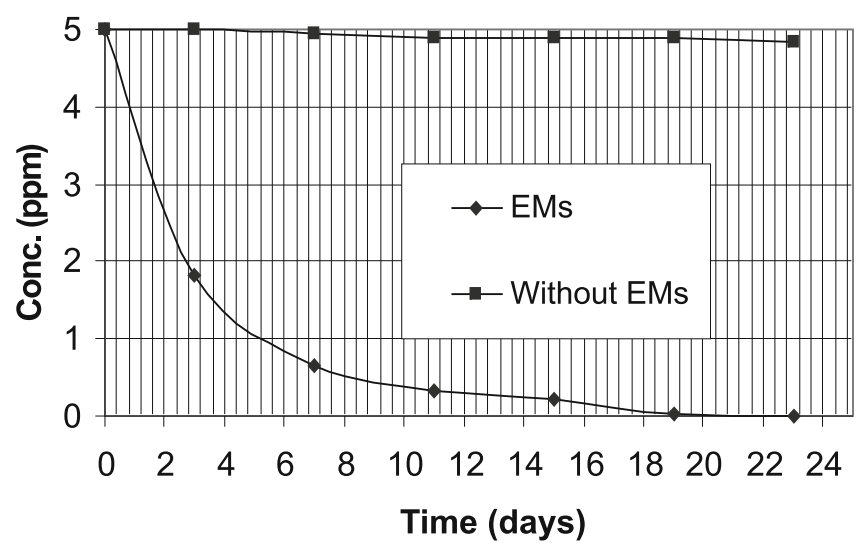

Figure 3. Biodegradation of chlorpyrifos at the initial concentration of $5 \mathrm{mg} \mathrm{L}^{-1}$ in drinking water by effective microorganisms (EMs) degradation ability must be faster and more effective than using one microorganism. The main species involved in EMs include: lactic acid bacteria (Lactobacillus plantarum, Lactobacillus casei and Streptoccus lactis), photosynthetic bacteria (Rhodopseudomonas palustrus and Rhodobacter spaeroides) yeasts (Saccharomyces cerevisiae, Candida utilis), actinomycetes (Streptomyces albus and Streptomyces griseus) and fermenting fungi (Aspergillus oryzae and Mucor hiemalis) ${ }^{\mathbf{4 8}}$.

The results revealed that chlorpyrifos might have been metabolized efficiently by detoxifying enzymes. Since the biodegradation of organophosphates involve activities of enzymes such as phosphatase, esterase, hydrolase and oxygenase. Enzymatic hydrolysis of twelve commonly used organophosphorus insecticides was found to be much faster than chemical hydrolysis ${ }^{49}$.

As a conclusion, effective microorganisms could be used in various kinds of aerobic and anaerobic systems for treating agricultural wastes which represent the first point of discharge of many chemicals into the environment. The effective and stable degradation capacity of this EMs technology in utilizing and degrading this compound reflected their efficacy in biotechnological application for the bioremediation of such contaminated water. These results indicated that EMs are more stable in retaining their ability to completely degrade chlorpyrifos because these effective microorganisms live in symbiotic relationships and their influence on the environment are sum of all activities of these microorganisms. Where the metabolites formed by one type of microorganism may be utilized by other group of organisms. Therefore, this study so far suggested that micro-organisms endowed with this property of degradation of toxic pollutants are a boon to mankind. Future studies on the genes responsible for enhanced biodegradation will enable us to elucidate the exact degradation pathway involved in its microbial biodegradation.

\section{Toxicity assessment}

\section{Cholinesterase activity}

The complete detoxification of chlorpyrifos in water samples treated with $\mathrm{Fe}_{2} \mathrm{O}_{3}$ (nano) $/ \mathrm{H}_{2} \mathrm{O}_{2} / \mathrm{UV}, \mathrm{ZnO}$ (nano)/ $\mathrm{H}_{2} \mathrm{O}_{2} / \mathrm{UV}, \mathrm{Fe}^{3+} / \mathrm{H}_{2} \mathrm{O}_{2} / \mathrm{UV}, \mathrm{ZnO} / \mathrm{H}_{2} \mathrm{O}_{2} / \mathrm{UV}$ and effective microorganisms (EMs) was confirmed by measuring the effect of these samples on the activity of acetyl cholinesterase relative to control in treated rats. The results showed that there were no significant differences in cholinesterase activity in the serum of the rats treated with water samples after remediation relative to control treatment (Table 3).

Table 3. The effect of different chlorpyrifos contaminated water treatments on the activity of cholinesterase in rat relative to control treatment

\begin{tabular}{|l|c|}
\hline Treatments & Cholinesterase activity $\left(\mathrm{U} \mathrm{L}^{-1}\right)$ \\
\hline $\mathrm{Fe}_{2} \mathrm{O}_{3}$ (nano)/ $\mathrm{H}_{2} \mathrm{O}_{2} / \mathrm{UV}$ & $918 \pm 8.1 \mathrm{a}$ \\
\hline $\mathrm{Fe}^{+3} / \mathrm{H}_{2} \mathrm{O}_{2} / \mathrm{UV}$ & $919 \pm 9.2 \mathrm{a}$ \\
\hline $\mathrm{ZnO} / \mathrm{H}_{2} \mathrm{O}_{2} / \mathrm{UV}$ & $922 \pm 5.7 \mathrm{a}$ \\
\hline $\mathrm{ZnO}($ nano $) / \mathrm{H}_{2} \mathrm{O}_{2} / \mathrm{UV}$ & $919 \pm 6.4 \mathrm{a}$ \\
\hline $\begin{array}{l}\mathrm{Effective} \mathrm{microorganisms} \\
\text { (EMs) }\end{array}$ & $914 \pm 3.7 \mathrm{a}$ \\
\hline Control & $918 \pm 4.2 \mathrm{a}$ \\
\hline LSD & 4.41 \\
\hline
\end{tabular}

$\% \mathrm{C}=$ activity of $\mathrm{AChE}$ in treatment / activity of AChE in control $\mathrm{x} 100$ ${ }^{*} \mathrm{UL}^{-1}=$ Unit per liter 

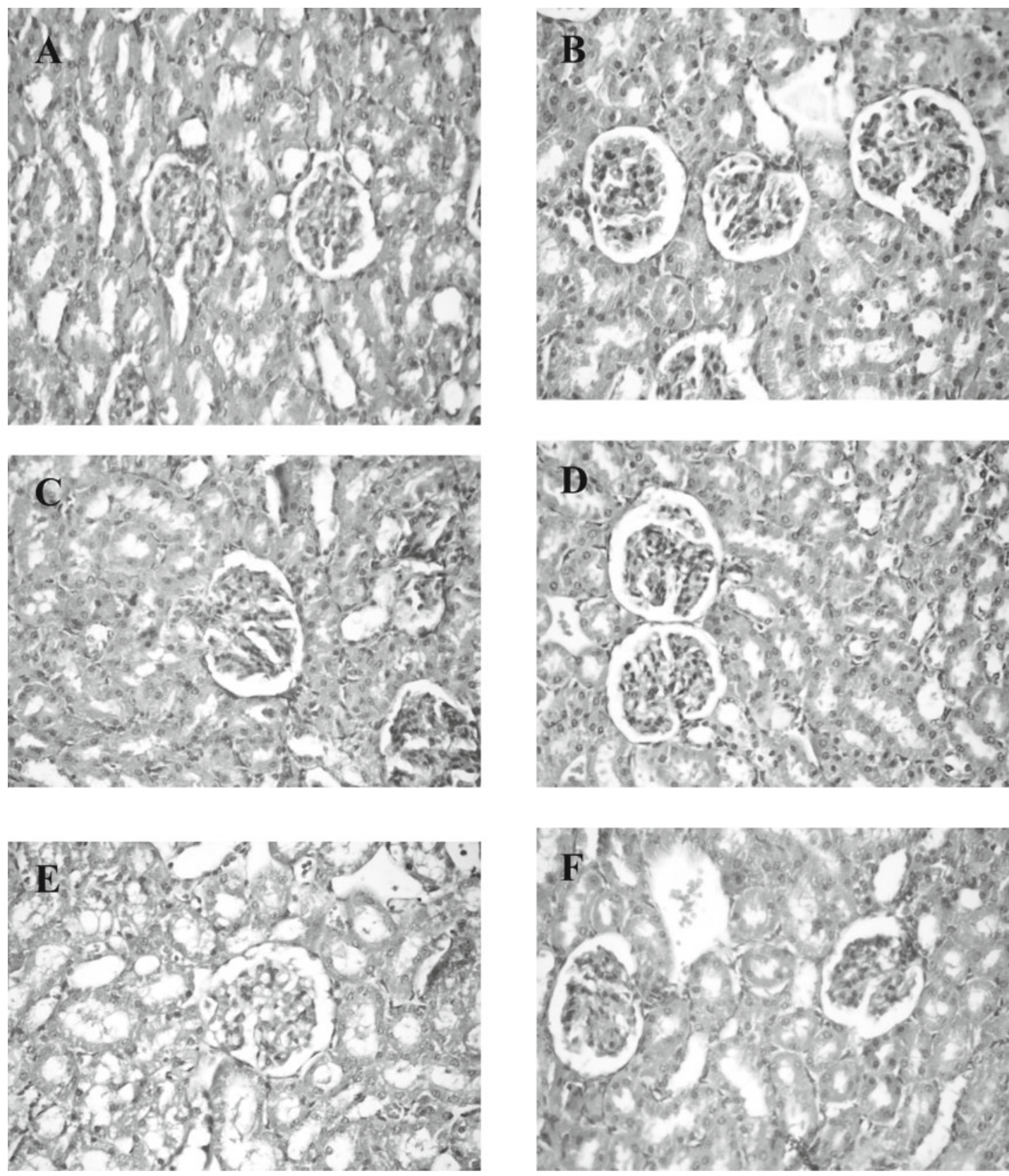

Figure 4. Sections in the kidney of rats treated with chlorpyrifos after remediation with $\mathrm{Fe}_{2} \mathrm{O}_{3}(\mathrm{nano}) / \mathrm{H}_{2} \mathrm{O}_{2} / \mathrm{UV}(\mathrm{B}), \mathrm{Fe}^{+3} / \mathrm{H}_{2} \mathrm{O}_{2} /$ $\mathrm{UV}$ (C), $\mathrm{ZnO}\left(\right.$ nano) $/ \mathrm{H}_{2} \mathrm{O}_{2} / \mathrm{UV}$ (D), $\mathrm{ZnO} / \mathrm{H}_{2} \mathrm{O}_{2} / \mathrm{UV}$ (E) and effective microorganisms (F) relative to control (A)

\section{Histology test}

\section{The histopathological changes in the kidney}

The normal structure of kidney tissue is shown in Fig. 4 A. For the rats treated with chlorpyrifos after remediation with $\mathrm{Fe}_{2} \mathrm{O}_{3}$ (nano) $/ \mathrm{H}_{2} \mathrm{O}_{2} / \mathrm{UV}$ (B), $\mathrm{Fe}^{3+} / \mathrm{H}_{2} \mathrm{O}_{2} /$ $\mathrm{UV}$ (C), $\mathrm{ZnO}$ (nano) $/ \mathrm{H}_{2} \mathrm{O}_{2} / \mathrm{UV}$ (D), $\mathrm{ZnO} / \mathrm{H}_{2} \mathrm{O}_{2} / \mathrm{UV}$ (E) and Effective microorganisms $(\mathrm{F})$, the tissues were normal as control but for small vaculations of endothelial lining glomerular tult and epithelial lining renal tubules (Fig. 4 E). To confirm the safety of the materials used in the remediation, some rats were treated with $\mathrm{Fe}_{2} \mathrm{O}_{3}$ (nano) $/ \mathrm{H}_{2} \mathrm{O}_{2} / \mathrm{UV}$ (B), $\mathrm{Fe}^{3+} / \mathrm{H}_{2} \mathrm{O}_{2} / \mathrm{UV}$ (C), $\mathrm{ZnO}-$ (nano) $/ \mathrm{H}_{2} \mathrm{O}_{2} / \mathrm{UV}$ (D), $\mathrm{ZnO} / \mathrm{H}_{2} \mathrm{O}_{2} / \mathrm{UV}$ (E) and Effective microorganisms $(\mathrm{F})$ without chlorpyrifos and the kidney tissues were normal as control (data not published).

\section{The histopathological changes in the liver}

The normal structure of liver tissue is shown in Fig. 5 A. For the rats treated with chlorpyrifos after remediation with $\mathrm{Fe}_{2} \mathrm{O}_{3}$ (nano) $/ \mathrm{H}_{2} \mathrm{O}_{2} / \mathrm{UV}$ (B), $\mathrm{Fe}^{3+} / \mathrm{H}_{2} \mathrm{O}_{2} / \mathrm{UV}$ (C),
$\mathrm{ZnO}$ (nano) $/ \mathrm{H}_{2} \mathrm{O}_{2} / \mathrm{UV}$ (D), $\mathrm{ZnO} / \mathrm{H}_{2} \mathrm{O}_{2} / \mathrm{UV}$ (E) and Effective microorganisms $(\mathrm{F})$, the tissues similar with that in control but for hydropic degeneration of hepatocytes (Figs. 5 B, E) and small vacueles in cytoplasm of some hepatocytes (Figs. 5 F). To confirm the safety of materials used in the different remediation processes, some rats treated with $\mathrm{Fe}_{2} \mathrm{O}_{3}$ (nano) $/ \mathrm{H}_{2} \mathrm{O}_{2} / \mathrm{UV}$ (B), $\mathrm{Fe}^{3+} / \mathrm{H}_{2} \mathrm{O}_{2} / \mathrm{UV}$ (C), $\mathrm{ZnO}$ (nano) $/ \mathrm{H}_{2} \mathrm{O}_{2} / \mathrm{UV}$ (D), $\mathrm{ZnO} / \mathrm{H}_{2} \mathrm{O}_{2} / \mathrm{UV}$ (E) and Effective microorganisms (F) without chlorpyrifos and liver tissues were normal as control (data not published).

To evaluate the efficacy of different tested remediation techniques in removing chlorpyrifos from drinking water, toxicity assessment was carried out with respect to biochemical and histological tests. The results showed that the treated water samples either after chemical or bio remediation had no significant effect on the activity of AChE relative to control (Table 3). This is implied that chlorpyrifos which spiked in water samples before remediation was completely removed in all remediation techniques. Also this means that the aqueous solution 

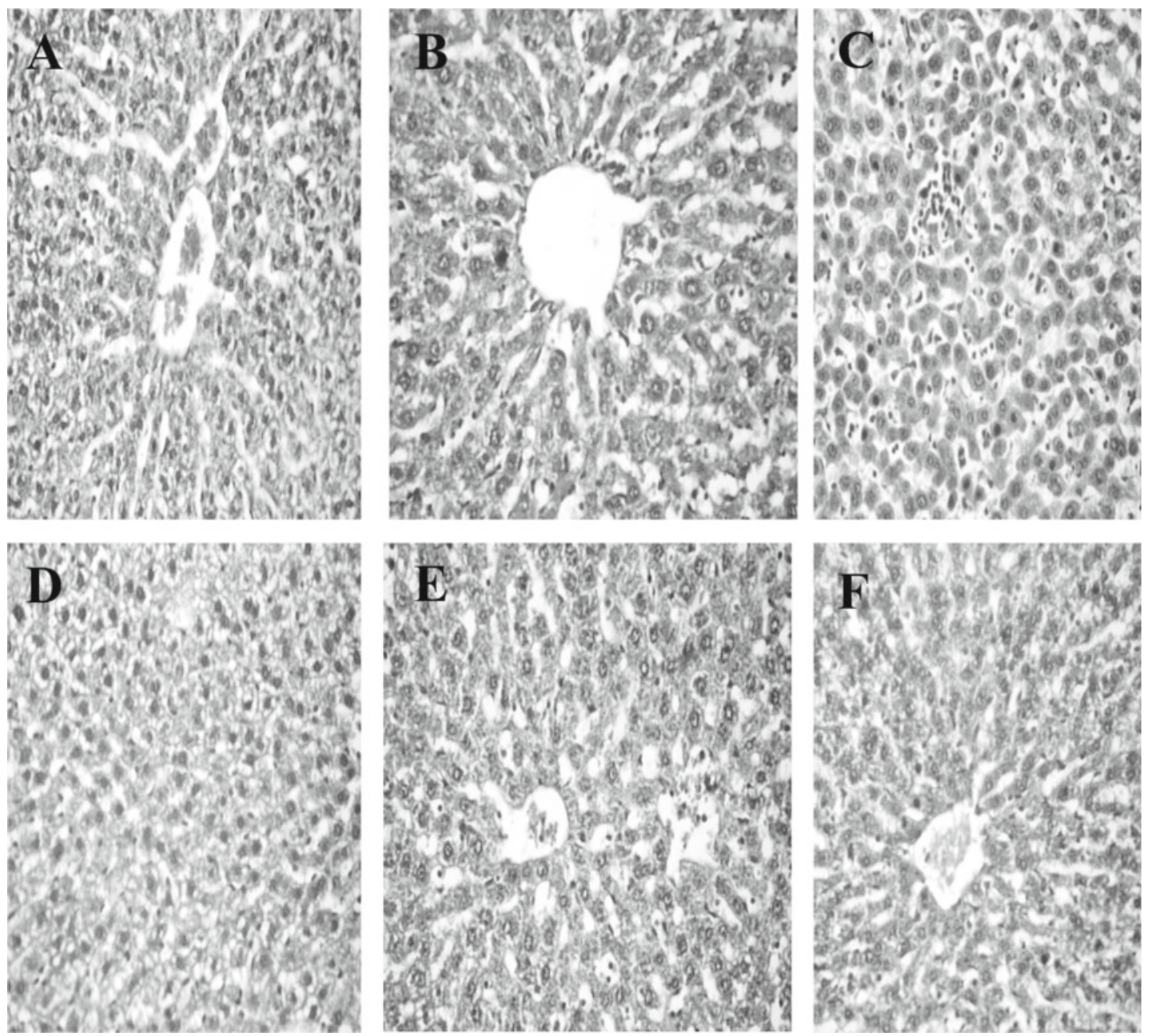

Figure 5. Sections in the liver of rats treated with chlorpyrifos after remediation with $\mathrm{Fe}_{2} \mathrm{O}_{3}($ nano $) / \mathrm{H}_{2} \mathrm{O}_{2} / \mathrm{UV}(\mathrm{B}), \mathrm{Fe} \mathrm{C}^{+3} / \mathrm{H}_{2} \mathrm{O}_{2} / \mathrm{UV}$ (C), $\mathrm{ZnO}$ (nano)/ $\mathrm{H}_{2} \mathrm{O}_{2} / \mathrm{UV}$ (D), $\mathrm{ZnO} / \mathrm{H}_{2} \mathrm{O}_{2} / \mathrm{UV}$ (E) and Effective microorganisms (F) relative to control (A)

spiked with chlorpyrifos was completely detoxified to AChE non-inhibiting products when a bioassay was conducted with $\mathrm{AChE}$ as a sensitive target of chlorpyrifos ${ }^{21}$. The histological test for all remediation techniques of chlorpyrifos in drinking water showed no significant changes in kidney or liver of treated rats relative to control treatment. This implies the complete detoxification of chlorpyrifos and its possible toxic products in treated drinking water with different remediation techniques. Also, this reflect the safety of all the tested chemical and biological remediation techniques on human health especially when we extend the remediation time for photochemical and bioremediation techniques.

Advanced oxidation processes especially with nanomaterials and bioremediation using effective microorganisms are promising remediation technologies for chlorpryifos removing in water. However, advanced oxidation processes especially with nanomaterials can more suitable remediation technologies for water (fresh or waste) contaminated with high concentrations due to its faster degradation due to its great degradation power relative bioremediation using effective microorganisms that takes a long time, need special environmental conditions and limited to those compounds that are biodegradable ${ }^{21}$. On the other hand, bioremediation using effective microorganisms could be more suitable for drinking water contaminated with low concentrations and low persistent compounds due its safety relative to chemical remediation by advanced oxidation processes. Although nanomaterials present seemingly limitless possibilities, they bring with them new challenges to understanding, predicting and managing potential safety and health risks to workers. Although the toxicological tests in this study showed that nanomaterials could be safe the implications of these engineered nanoparticles, which may have different particle properties, are uncertain. Research is needed to determine the key physical and chemical characteristics of nanoparticles that determine their hazard potential ${ }^{50}$.

\section{CONCLUSIONS}

These results clearly indicate the presence of numerous organophosphorus compounds in drinking water. Water purification processes reduced the amount of pesticides in drinking water. The photo-Fenton like reagent and photo zinc oxide combined with hydrogen peroxide showed much promise in the complete degradation and detoxification of chlorpyrifos in contaminated drinking water, especially by using ferric and zinc oxides nanoparticles. Effective microorganisms' formulation is promising an effective and safe bioremediation technique for chlorpyrifos removal in drinking water.

\section{ACKNOWLEDGEMENTS}

The authors thanks the financial supports providing from university of Kafrelsheikh, sector of postgraduate and research affairs, university research fund (Project No. KFUR03) in 2010. 


\section{LITERATURE CITED}

1. Tankiewicz, M., Fenik, J. \& Biziuk, M. (2010). Determination of organophosphorus and organonitrogen pesticides in water samples ends in. Anal. Chem. 29, 1050-1063. DOI: 10.1016/j.trac.2010.05.008.

2. Sosnowska, K., Styszko-Grochowiak, K. \& Gołas, J. (2009). Emerging contaminants in aquatic environment-sources, risk and analytical problems Anal. 4, 44-48.

3. McKinlay, R., Plant, J.A., Bell, J.N.B. \& Voulvoulis, N. (2008). Endocrine disrupting pesticides: Implications for risk assessment Environ. Inter., 34, 2, 168-183. DOI: 10.1016/j. envint.2007.07.013.

4. Lasram, M.M., Annabi, A.B., El-Elj, N., Selmi, S., Kamoun, A., El-Fazaa, S. \& Gharbi, N. (2009). Metabolic disorders of acute exposure to malathion in adult wistar rats. J. Hazard. Mat. 163, 1052-1055. DOI:10.1016/j.jhazmat.2008.07.059.

5. Derbalah, A.S. (2009). Chemical remediation of carbofuran insecticide in aquatic system by advanced oxidation processes. J. Agric. Res. Kafr Elsheikh Univ. 35 (1), 308-327.

6. Shawaqfeh, A.T. \& Al Momani, F.A. (2010). Photocatalytic treatment of water soluble pesticide by advanced oxidation technologies using UV light and solar energy. Solar Energy, 84, 1157-1165.

7. Francisca, M.C., Vilar, V.J.P., Ferreira, Ana, F.C.C., Felipe, D.R.A. \& Márcia, D., Sousa, M.A., Goncalves, C., Boaventura Rui, A.R. \& Alpendurada, M.F. (2012). Treatment of a pesticide-containing wastewater using combined biological and solar-driven AOPs at pilot scale Chem. Eng. J. 209, 429-441. DOI: $0.1016 / j . c e j .2012 .08 .009$.

8. Derbalah, A.S., Nakatani, N. \& Sakugawa, H. (2004). Photocatalytic removal of fenitrothion in pure and natural waters by photo-Fenton reaction. Chemosphere, 57, 635-644. DOI: $10.1016 / \mathrm{j}$.

9. Lines, M.G. (2008). Nanomaterials for practical functional uses. J. Alloys Compd, 449, 242-245. DOI: 10.1016/j.

10. Mamalis, A.G. (2007). Recent advances in nanotechnology. J. Mat. Process. Technol. 181, 52-58.

11. Miyazaki, K. \& Islam, N. (2007). Nanotechnology systems of innovation - an analysis of industry and academia research activities. Technovation, 27, 661-675. DOI: 10.1016/j. technovation.2007.05.009.

12. Cuenya, B.R. (2010). Synthesis and catalytic properties of metal nanoparticles: Size, shape, support, composition, and oxidation state effects. Thin Solid Films. 518, 3127-3150. DOI: 10.1016/j.tsf.2010.01.018.

13. Theng, B.K.G. \& Yuan, G. (2008). Nanopaticles in the soil environment. Elements 4, 395-399.

14. Feng, J., Hu, X. \& Yue, P.L. (2004 a). Novel bentonite clay-based $\mathrm{Fe}$-nanocomposite as a heterogeneous catalyst for photo-Fenton discoloration and mineralization of Orange II. Environ. Sci. Technol. 38, 269-275.

15. Feng, J., Hu, X. \& Yue, P.L. (2004 b). Discoloration and mineralization of Orange II using different heterogeneous catalysts containing Fe: a comparative study. Environ. Sci. Technol. 38, 5773-5778.

16. Valdés-Solís, T.P., Valle-Vigón, P., Álvarez, S., Marbán, G. \& Fuertes, A.B. (2007 a). Encapsulation of nanosized catalysts in the hollow core of a mesoporous carbon capsule. J. Catal. 251, 239-243. DOI: 10.1016/j.jcat.2007.07.006.

17. Valdés-Solís, T.P., Valle-Vigón, P., Álvarez, S., Marbán, G. \& Fuertes, A.B. (2007 b). Manganese ferrite nanoparticles synthesized through a nanocasting route as a highly active Fenton catalyst. Catal. Commun. 8, 2037-2042. DOI: 10.1016/j. catcom.2007.03.030.

18. Zelmanov, G., Semiat, R. (2008). Iron(3) oxide-based nanoparticles as catalysts in advanced organic aqueous oxidation. Wat. Res. 42, 492-498. DOI: 10.1016/j.watres.2007.07.045.

19. Nurmi, J., Tratnyek, P.G., Sarathy, V., Baer, D.R., Amonette, J.E., Pecher, K., Wang, C., Linehan, J.C., Matson, D.W.,
Penn, R.L. \& Driessen, M.D. (2005). Characterization and properties of metallic iron nanoparticle: spectroscopy, electrochemistry, and kinetics. Environ. Sci. Technol. 39, 1221-1230. DOI: 10.1021/es049190u.

20. Megharaj, M., , Ramakrishnan, B., Venkateswarlu, K., Sethunathan, N. \& Naidu, R. (2011). Bioremediation approaches for organic pollutants: A critical perspectiveReview Environ. Inter. 37, 1362-1375.

21. Vidali, M. (2001). Bioremediation. An overview. Pure Appl. Chem. 73 (7): 1163-1172 . DOI: 10.1351/pac200173071163.

22. Kralj, M.B., Franko, M. \& Trebse, P. (2007). Photodegradation of organophosphorus insecticides-Investigations of products and their toxicity using gas chromatography-mass spectrometry and AChE-thermal spectrometric bioassay. Chemosphere 67, 99-107. DOI: 10.1016/j.chemosphere.2006.09.039.

23. Simonian, A.L., Efremenko, E.N. \& Wild, J.R. (2001). Discriminative detection of neurotoxins in multi-component samples. Anal. Chim. Acta 444, 179-186.

24. Abdel-Halim, K.Y., Salama, A.K., El-Khateeb, E.N. \& Bakry, N.M. (2006). Organophosphorus pollutants (OPP) in aquatic environment at Damietta Governorate, Egypt: Implications for monitoring and biomarker responses. Chemosphere 63, 1491-1498. DOI: 10.1016/j.chemosphere.2005.09.019.

25. Abdel-Megeed, A. (2004). Psychrophilic degradation of long chain alkanes, Unpublished doctoral dissertation, Technical University Hamburg-Harburg, Germany. pp. 158.

26. Derbalah, A.S., Massoud, A.H. \& Belal, E.B. (2008). Biodegrability of famoxadone by various microbial isolates in aquatic system. Land Contamination \& Reclama. 16 (1), 13-23. DOI: 10.2462/09670513.876.

27. Ellman, G.L., Courtney, K.D., Andres, V. \& Featherstone, R.M. (1961). A new and rapid calorimetric determination of acetyl cholinesterase activity. Biochem. Pharmacol. 7, 88-95.

28. Bancroft, J.D. \& Stevens, A. (1996). Theory and Practice of Histological Techniques. (4th ed.). Churchill Livingstone. Edinburg, London, Melbourne and New York.

29. Abd-Allah, S.W. \& Hesham, M.G. (2003). Monitoring of pesticide residues in different sources of drinking water in some rural areas. Alex. J. Agric. Res. 48 (3), 187-199.

30. Ashry, M.A., Bayoumi, O.C., El-Fakharany, I.I., Derbalah, A.S. \& Ismail, A.A. (2006). Monitoring and removal of pesticides residues in drinking water collected from Kafr El-Sheikh governorate, Egypt. J. Agric. Res. Tanta Univ. 32 (3), 691-704.

31.Aizawa, M.Y.T., Matumoto, N. \& Ouna, F. (1994). Degradation of Pesticides by Chlorination During Water Purifi cation. Groundwater Contamination, Environmental Restoration, and Diffuse Source Pollution. Water Sci. Tech. 30, 119-128.

32. Aslan, S. (2005). Combined removal of pesticides and nitrates in drinking waters using biodenitrification and sand filter system Process. Biochem. 40, 417-424. DOI: 10.1016/j. procbio.2004.01.030.

33. Ayranci, E. \& Hoda, N. (2005). Adsorption kinetics and isotherms of pesticides onto activated carbon-cloth. Chemosphere. 60, 1600-1607. DOI: 10.1016/j.chemosphere.2005.02.040 .

34. Matilainen, A., Vepsäläinen, M. \& Sillanpää, M. (2010). Natural organic matter removal by coagulation during drinking water treatment. A Rev. Advances in Colloid and Interface Sci. 159,189-197. DOI: org/10.1016/j.cis.2010.06.007.

35. Sarkar, B.N., Venkateswralu, R., Nageswara, B., Hattacharjeec, C. \& Kalea, V. (2007). Treatment of pesticide contaminated surface water for production of potable water by a coagulation-adsorption-nanofiltration approach. Desalination 212, 129-140. DOI: 10.1016/j.desal.2006.09.021.

36. He, F., Zhao, D., Liu, J. \& Roberts, C.B. (2007). Stabilization of $\mathrm{Fe}-\mathrm{Pd}$ nanoparticles with sodium carboxymethyl cellulose for enhanced transport and dechlorination of trichloroethylene in soil and groundwater. Indian Engineer. Chem. Res. 46, 29-34. DOI: 10.1021/ie0610896.

37. He, F. \& Zhao, D. (2005). Preparation and characterization of a new class of starch-stabilized bimetallic nanoparticles 
for degradation of chlorinated hydrocarbons in water. Environ. Sci. Technol. 39,3314-3320. DOI:10.1021/es048743y.

38. Hayashi, H., Nakajima, Y. \& Ohta, K. (2007). Novel degradation method of organic compounds in human surroundings using iron oxide. Rep. Technol. Res. Institute Osaka Pref. 21, 79-83. DOI: 10.1016/j.chemosphere.2010.11.052.

39. Takuya, M., Tokumura, M., Sekine, M. \& Kawase, Y. (2011). Hydroxyl radical concentration profile in photo-Fenton oxidation process: Generation and consumption of hydroxyl radicals during the discoloration of azo-dye Orange II. Chemosphere 82, 1422-1430. DOI: 10.1016/j.chemosphere.2010.11.052.

40. Noorjahan, M., Kumari, V.D., Subrahmanyam, M. \& Panda, L. (2005). Immobilized Fe(III)-HY: an efficient and stable photo-Fenton catalyst. Appl. Catal., B 57, 291-298.

41. Pare, B.P., Singh, S. \& Jonnalagadda, B. (2008). Visible light induced heterogeneous advanced oxidation process to degrade pararosanilin dye in aqueous suspension of $\mathrm{ZnO}$. Indian J. Chem. 4, 830-835.

42. Kwan, W.P. \& Voelker, B.M. (2003). Rates of hydroxyl radical generation and organic compound oxidation in mineral-catalyzed Fenton-like systems. Environ. Sci. Technol. 37, 1150-1158. DOI: 10.1021/es020874g.

43. Wang, H., Xie, C., Zhang, W., Cai, Z., Cai, S., Yang, Z. \& Gui, Y. (2007). Comparison of dye degradation efficiency using $\mathrm{ZnO}$ powders with various size scales. J. Hazard. Mat. 141, 645-652.

44. Garrido-Ramírez, E.G., Theng, B.K.G. \& Mora M.L. (2010). Clays and oxide minerals as catalysts and nanocatalysts in Fenton-like reactions - A review Applied Clay Science 47, 182-192. DOI: 10.1016/j.clay.2009.11.044.

45. Higa, T. (1995). What is EM Technology. College of Agriculture, University of Ryukyus, Okinawa, Japan.

46. EM Technology. (1998). Effective Microorganisms for a Sustainable Agriculture and Environment. From Link http:// emtech.org/prod01.htmm.

47. EM Trading (2000). Effective Microorganisms (EM) from Sustainable Community Development. From EM Technology Product Link http://www.emtrading.com.html.

48. Diver, S. (2001). Nature Farming and Effective Microorganisms', Rhizosphere II: Publications. from Steve Diver Link http://ncatark.uark.edu/ steved/Nature-Farm-EM.html.

49. Mulbry, W. \& Karns, J. (1989). Purification and characterization of three parathion hydrolases from gram-negative bacterial strains. Appl. Environ. Microbiol. 55, 289-293.

50. Borm, P.J., David Robbins, D., Haubold, S., Kuhlbusch, T., Fissan, H., Donaldson, K., Schins, R., Stone, V., Kreyling, W., Lademann, J., Krutmann, J., Warheit, D. \& Oberdorster, E. (2006). The potential risks of nanomaterials: a review carried out for ECETOC. Particle \& Fibre Toxicol. 3, 1-35. DOI: $0.1186 / 1743-8977-3-11$. 